\title{
Special Aspects of Horse Husbandry Production Costs Calculation
}

Klychova G.S.

Kazan Federal University, Institute of Management, Economics and Finance, Kazan, 420008, Russia

Zakirova A.R.

Kazan State Agrarian University Kazan, 420015, Russia

Khametova M.V.

Kazan State Agrarian University Kazan, 420015, Russia

Sadrieva E.R.

Kazan State Agrarian University Kazan, 420015, Russia

Email:kgaukgs@mail.ru

\section{Doi:10.5901/mjss.2014.v5n24p91}

\section{Abstract}

\begin{abstract}
The given article considers the special aspects of horse husbandry production costs calculation and proposes the scientificmethodological approach of its optimization. Utilization of this approach will make possible to determine a well-reasoned cost of product produced and the data received thereby will serve as the basis for rational decision-making in the field of strategic management and manufacturing activity planning. Data base of cost management in horse breeding development is certainly a complex process that involves planning, valuation, accounting, analysis, effective cost control and management, forecasting, and making appropriate decisions to prevent negative results.
\end{abstract}

Keywords: output cost determination, production cost, expenses, horse husbandry, items of calculation.

\section{Introduction}

Output cost determination appears to be one of the main aspects of bookkeeping and theoretically substantiated method of cost accounting. At agricultural undertakings cost determination is used for: establishing the level of break-even price, cost of goods manufactured control, calculating efficiency of technological, zoocultural and organizational measures being planned and implemented in industrial activity development and estimation of produce profitability. Since output cost determination completes the last stage of production costs accounting, it plays an important part in obtaining verifiable information with regard to cost management in horse husbandry.

\section{Theory}

At estimating output cost production a well-reasoned choice of calculation items and revenue unit of service what makes possible to production costs determination

Different processes act in the function of accounting entity and as the items of calculation serve separate kinds of produce received in the production process. In horse husbandry the main accounting entities are the reproductive herd and youngsters being grown. The items of calculation are the following:

1) according to the reproductive herd: milk, animal yield, colt body-weight increase and work;

2) according to youngsters being grown- body-weight increase.

Revenue unit of service is an adopted unit to measure the item of calculation in real terms: milk (1 c), animal yield (heads), colt body-weight increase $\Pi$ ( $1 \mathrm{c}$ ), work (1 work day). Considering that horse youngsters is not weighted the body-weight increase should be estimated not in centners but to determine the self-cost of one feed- day, i.e. of one day of animal housing (Figure 1). 


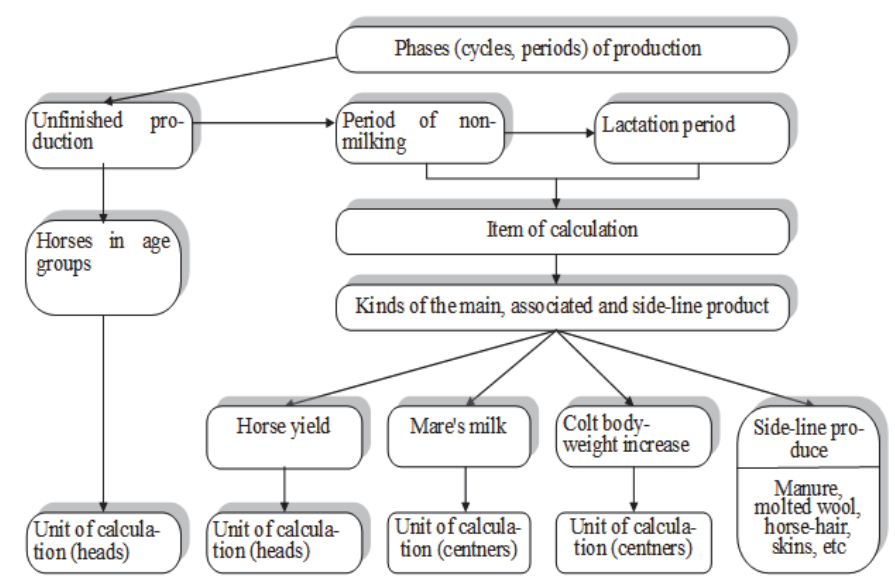

Fig.1. Stages and items of horse husbandry production cost calculation at phase method of cost accounting

Moreover, at calculating production costs it should be useful to establish an accounting period and to determine the method of accounting. The accounting period in horse husbandry is considered to be a calendar year what is not at all correlated with technological aspects of the given industry and trespasses against the principle of compliance. In other words, expenses for brood horses growing and housing of the given calendar year is impossible to refer to this year's manufacture of products as the production cycle in brood horse husbandry makes 3-5 years.

At present production cost accounting in horse husbandry is implemented by means of mixed method that implies the use of several techniques: method of expenses involved in side-line produce exclusion and non-process method. The method of expenses involved in side-line produce exclusion is applied at production costs accounting and lies in the fact that according to their structure the manufactured products are divided into the main and side-line produce. In doing so, merely the main produce is accounted. The side-line produce in horse husbandry comprises manure, molted wool, horsehair, skins and fallen animals' recycled meat. The side-line produce is estimated by previously fixed prices. At accounting the main produce the value of production is subtracted from the total sum of expenses. The remaining amount will present the costs of the main produce. The main disadvantage of this approach is that in practice not all the side-line produce is entered into accounting records. As a consequence, the main produce cost is deliberately overestimated.

Application of one or another method of costing is influenced by production description, the intended use of a manufactured product and the duration of the cost-accounting period. The use of only one of the widely used existing methods does not make possible to determine certain kinds of produce cost size to the full extent and produce costeffectiveness analysis.

Cost accounting in horse husbandry is necessary to arrange in compliance with the special aspects of technology and manufacture in the given industry. It should be noted that production process in brood horse husbandry is monitored according to technological process stages by reference to specific features of brood horses' youngsters housing, i.e. each technological stage in youngsters growing, mare's milk and koumiss (fermented mare's milk) production has its own peculiarities. The initial stage of youngstock growing up to 2 years both in efficient horse husbandry and on stud farm appears to be the type of mass production of brood horse husbandry with primarily group housing. The first stage of brood horse-breeding production must be characterized by the availability of non-process cost accounting items and breeder youngsters costing. At the stage of breeding up to 6-7 months age the suckling colts are housed together with mares and they are fed by primarily mare's milk. Gradually the colts are trained to follow the dam and later on the mares and colts are combined in groups. In dairy horse husbandry the mares within 30 days after colting are batched in groups to be accustomed to machine milking and the mares with foal at foot are transferred to group cubicle houses by 12-15 dams with foals per cubicle. Since the one-month age the specific weight of supplementary feeding is gradually increased (including concentrated feeding, Calf Milk Replacer and premixes) to prepare them to weaning.

At horse breeding complexes the weaners are separated according to sex. The fillies come to the shop where they are batched into three age -groups:

1) after weaning from 8 months up to 1 year;

2) older than 1 year to be grown for remount and sale;

3) older than 2 years for breeding.

Last group is designed for young mares' covering since a 2,5-year age. 
Colts after weaning also enter the shop where they are grown for remount and sale. Part of them beginning with a three- years- age is left in the quality of a breeder. The youngsters are housed in group cubicle houses and paddocks by 20-25 heads per a housing unit. Daily they are doing physical exercise in the field during two hours.

On brood stud farms the weaning colts are housed by pairs in box stalls. Colts and fillies are managed separately taking into account their advancement and temper. At the age of 6-12 months the colts-weaners are set to training. Action lessons for colts at this stage involve running in alternating pace with gradual enlargement of distance.

In 2-3 months after weaning begins the next stage of the colts breeding and housing when they are directed to hippodrome and where they are taught to be accustomed to horse harness, horseman crew and reining. They are also housed in groups and involved in compulsory action lessons. At the age of 18-24 months, at the next stage, the colts are trained individually. The goal of individual training is maximal development of horse working capacity by means of progressive load enlargement and youngsters' involvement in various paces (trot, extended canter). As a consequence of training the horses work out high action, hardinesss, ability to spurts and clear transition from one allure to another. Within this period it is wise to use phase method for cost accounting of brood horses' youngsters and their output cost determination.

The core products of koumiss farm are mare's milk, fermented mare's milk or koumiss and colts grown before the weaning. Production expenditures for koumiss manufacturing are accounted as a whole, according to production line, i.e. accounting of all expenditures are entered to a separate sub-ledger account. In case when an enterprise is engaged in permanent processing of the mare's milk and has its own koumiss workshop then cost accounting is necessary to implement according to separate technological operations. For instance, koumiss production costs are influenced by amount of expenses related to mare's milk and absorbed expenses of its processing. Self-cost of the mare's milk is shaped up from the amount of expenses for managing stallions and mares on a koumiss farm (including expenses for colts supplementary feeding and milking operations) but excluding cost of colts-weaners, male-horses and mares' work, manure and molted wool. Therewithal non-breeding colts are estimated by prices for beef cattle, but breeding coltsweaners - in size of $40 \%$ of sales price established for one horse of II category I class of the appropriate breed. The cost of mares and male-horses work is estimated by standard cost of a horse-day for a working horse, manure is accounted by fixed estimate and molted wool - by realizable value price.

Processing of mare's milk to produce koumiss comprises the following stages: ferment manufacture, koumiss production, bottling and cooling in refrigerating chamber. At koumiss output cost determining total sum of expenditures for koumiss farm management (excluding colts-weaners and side-line products cost) is divided into total quantity of koumiss produced. In other words, a simple (non-process) method of cost accounting and output cost determining is used.

\section{Results}

In brood horse husbandry the self-cost of animal yield (broodmares, stallions and colts before weaning) at birth and by the day of weaning (young animals per mother) is estimated by reproductive herd.

Colts self-cost at birth is estimated on the basis of the expenses for 60 feeding days of mares housing. To calculate the self-cost of one colt at birth the cost of the side-line product is subtracted from total sum of mares management and the remaining amount is divided by the number of the mares' feeding days then a one feeding day cost is multiplied by 60 .

On brood stud farms the core produce within a year is estimated according to target prime cost:

- $\quad$ foal crop of trotting breed by target prime cost of 60 days of feeding adult horses;

- foal crop of roadster breed by target prime cost of 60 days of feeding adult horses;

- foal crop of heavy harness horse breed in size of $80 \%$ of target prime cost for 60 days of feeding adult horses;

- mare's milk in the amount of $20 \%$ of target prime cost for 60 days of feeding adult horses;

- the cost of one head surplus young stock for a month is determined based on the established procedure of calculating 1 feeding day in housing youngsters of pure-blood roadster breed, Russian trotting breed and heavy harness horse breed.

For output cost determination of young animals per (one) mother (before weaning from a dam) the total cost of reproductive herd housing (excluding side-line products cost and cost of mares and stallions' work according to target prime cost of horse-day for working horses) is divided by the number of heads of young animals per (one) mother. The assessment of the indicated numbers of head is implemented by this prime cost in all directions of movement.

In brood horse husbandry the prime cost of horse youngsters' one head at the end of year and the cost of one head surplus are accounted according to group of all-age youngsters.

In the event the youngsters are being not weighed, the cost of one head surplus is determined on the assumption 
of calculating the number of feeding days in horse housing and average cost of one feeding day. At calculating the cost of one feeding day the expenditures for horse housing minus cost of the side-line produce are divided by the number of feeding days. At accounting the cost of youngsters one head surplus the cost of one feeding day is multiplied by the number of feeding days according to the given youngsters group.

The expenditures associated with work horses are allocated to that kind of product for which manufacture draftcattle was used. While assigning expenses on kinds of produce one horse-day (one day of horse's work) is used as a conventional measure.

At one horse-day prime cost determination the following expenses are accounted:

- labour cost with charges to horsekeepers and other workers engaged in adult horses servicing;

- the cost of foodstuff and horse-litter;

- depreciation and current repair of stable facilities and of equipment;

- other direct costs (electric power and water supply);

- general production expenses and general running costs allocated to work horses in the established order.

The amount of expenses does not comprise the costs of work horse youngsters as well as the expenses on labour remuneration for riding horsemen and other workers engaged in draft-cattle servicing. Then, the cost of one is determined by dividing the difference of annual expenses sum and side-line products cost by the total number of days in the given organization' horse housing. The cost of a work horse's colt is equated to the cost of 60 feeding days.

The foal crop total cost is estimated by multiplying the cost of one feeding day by 60 and by the number of youngsters produced.

The cost of one horse-day in the horse work is accounted according to the formula:

$S k d=(Z-((Z-P) / K D) * 60 \mathrm{Zh}-\mathrm{P}) / \mathrm{GVkd}(1)$

where, Skd - the cost of one horse-day;

Z - total cost of work horse housing;

$\mathrm{P}$ - side-line products cost (minus foal crop cost);

$\mathrm{Zh}$ - number of youngsters produced;

$\mathrm{KD}$ - number of feeding days in the year;

GVkd - annual horse days output.

Once in a while, we may need to refer to the determination of average annual unit for a certain kind of work (harrowing hectare, ton -kilometer of transportation), then we may use the formula:

$\mathrm{Sr}=((\mathrm{Skd} / \mathrm{RD})+\mathrm{OT}) / \mathrm{VR}(2)$

where, $\mathrm{Sr}$ - cost of the given kind of work unit;

Skd - the cost of one horse-day;

$\mathrm{RD}$ - work days number (horse-days produced);

OT - remuneration of labor for the whole accounting period to workers engaged in the given kind of work;

VR - completed work amount in the accepted units.

The technique of determining foal cost at birth and by the moment of weaning needs to be thoroughly studied. The existing method for output foal cost determination at birth and by the moment of weaning does not comply with technological requirements for fetus bearing and foal breeding after weaning as well as makes impossible to provide managerial staff with reliable information for making efficient managerial decisions in relation to costs management.

Mare's fetus is being formed within 11 months and is completed by colting only the next year. Therefore, absorbed expenses on in-foal mare housing since the moment of impregnation in the current year must be allocated to cost of the next year foal. In the process of the whole covering campaign and up to the latest terms of insemination in mid-June we can observe the effect of fetus bearing period displacement in relation to the accounting period. In this connection the expenses for impregnated mare housing should be accounted in the next accounting period. The fact that a foal's cost by the moment of birth is accounted in accordance with cost of 60 feeding days in a mares' housing is based on the assumption that fetus formation is more intensive within last two months. The given assumption can be used at determination of cost for only work horses since along with their foal crop production they are extensively used in internal works therefore it can be needed to determine the cost of one head of foal crop, one horse -day.

As the main goal and designation of broodmares' housing in horse husbandry is foal crop production, the existing method appears to be merely conventional and doesn't make possible to obtain the exact information for costs managing. In our opinion, the foal's cost by the moment of birth should comprise all the expenses on broodmares' housing within the period of pregnancy and the prior service - term apart from supplementary expenditures connected with suckling colts' breeding and works implementing. The mares' lactation period makes about 6 months and by the end of this term the mare has already been five months pregnant when the process of fetus formation is not so intensive. In order to allocate 
supplementary expenditures it is necessary to exclude permanent expenses for broodmare's maintenance feeding and include them into the cost of the next year foal, the rest of the expenditures being included into the cost of foals by the moment of their weaning.

Brood horse youngsters' cost after weaning is determined by summing up the costs of their housing in the accounting year which is defined by the number of the feeding days and one feeding day average cost as well as the cost of youngsters to be on the books as of the beginning of the year. The reality is that cost accounting of brood horse youngsters' management is estimated by direct costs summing up with their subsequent allocation in proportion to average annual head numbers of all age youngsters. In addition to the above it should be taken into account that the expenses on different age colts' housing and feeding (for instance, at the age of 6 months and two years) are varied widely. To put it differently, this information appears to be averaged and cannot serve as the basis for obtaining reliable data in relation to this industry cost management.

The most well-reasoned cost object providing trustworthy cost determination for brood horse youngsters at various stages of their breeding is one feeding day. For the purposes of accountable- analytical form of costs management in horse husbandry it is possible to propose dividing costs accumulation and accounting of one feeding day according to stages (phases) of breeding. This can be done by use of automated accounting record where accumulative cost accounting and one feeding day cost calculation is implemented according to each stage of youngsters' breeding within a certain period of time (a week, 10 days, etc.). This procedure will give an option of doing assessment for one feeding day cost change at each stage of brood youngsters breeding. In doing so, it is possible to calculate individual cost of a colt at each stage of his breeding at transfer to the senior age group and up to his sale, by the following formula:

$\mathrm{Szh}=\mathrm{Co}+\left(\right.$ Sk.d.i ${ }^{*} \mathrm{Di}$ * K) (3)

where,

Szh - a colt self-cost, rub.;

Co - a colt self-cost at birth,

Sk.d.i - cost of one feeding day in i-period, rub.;

$\mathrm{Di}-$ the duration of a colt housing in $\mathrm{i}$ - period of accounting;

$\mathrm{K}$ - number of accounting periods being included in a colt self-cost accounting.

The procedure of cost accounting and one feeding day cost calculation organized in this way requires no permanent calculation within the process of horse youngsters' breeding and gives an option of more exact determining a colt's cost at any stage of his breeding. In addition to the above, the use of up-to-date information technologies significantly diminishes labor effort as compared with manual accountable information processing [4].

Application of standard costing method for production expenses and output cost determination assumes compiling cost-information report where all calculations are stated. The cost-information report is made up by the accounting records of the manufactured produce quantity and actual expenditures. The cost-information reports are correlated with cost budget (standard) by means of uniform nomenclature of calculation items. Actual costing is applied to control the fulfillment of Key Performance Indicators and to diminish production costs. The cost-information reports comprise expenses and losses being not provided for cost budget, for instance, youngsters and adult horses' mortality, nonmonetary physical things inadequacy within the limits of natural loss rates. This will not bring about the violation of cost budget and cost-information reports compatibility but promote enhancement of supervising and analytical functions of accounting information. The cost-information reports makes possible to assess progressivity of the current norm for resources consumption and the efficient application of the organization's funds and, moreover, it appears to be one of the main sources of information at cost budgeting, economic cost analysis and cost prediction [2].

The main documents to be guided in horse husbandry output cost determination calculation comprise such specialized forms of documentation as «Cost calculation for one horse head housing» and «Calculation sheet of husbandry output actual costs determination».

"Cost calculation for one horse head housing» is used for cost calculation of housing one horse head according to brood youngsters and the reproductive herd separately as well as by each breed individually. The figures in the document are shown as of the beginning and the end of the accounting period what is necessary for implementing the most detailed and complete analysis of horse housing cost management to take managerial decisions.

«Calculation sheet of husbandry output actual costs determination» (see Table 1) is formed in compliance with «Methodological recommendations on book records of production cost accounting at the agricultural enterprises». The similar calculation sheet can be compiled in relation to youngsters being bred and koumiss production. The calculation sheet gives the possibility to monitor cost structure according to cost items both as a whole and per one horse head as well as per one litre of koumiss. The given document, its structure and content entirely comply with the requirements of production cost reporting preparation and is important in itself as the source of reliable information in compiling 
accountable-analytical data.

Table 1: Calculation sheet № of husbandry output actual costs determination for the year of 20XX.

3.1 Cost items structure (debit side of sub-ledger account reproductive herd

\begin{tabular}{|l|c|c|c|c|}
\hline \multirow{2}{*}{ Cost items } & \multicolumn{3}{|c|}{ Costs, total, thous.rub. } & \multicolumn{2}{l|}{ Costs per one head, thous.rub. } \\
\cline { 2 - 5 } & Actual & Budget & Actual & Budget \\
\hline Numbers of head & 164 & & & \\
\hline $\begin{array}{l}\text { 1. Related Costs } \\
\text { Individual Costs } \\
\text { a) feeding-stuffs }\end{array}$ & 1618,4 & 1600 & 9,87 & 9,75 \\
\hline c) means of animal protection & & & & \\
\hline d) oil products & 81,99 & 80,10 & 0,50 & 0,49 \\
\hline e) fuel and energy for the purposes of technology & 19,8 & 20,4 & 0,12 & 0,12 \\
\hline f) (main) direct labor cost & 22,5 & 21,1 & 0,14 & 0,13 \\
\hline g)(supplementary) direct labor cost & 673,26 & 670,0 & 1,63 & 1,65 \\
\hline h) allocations for social requirements of production workers & 191,3 & 190,4 & 1,17 & 1,16 \\
\hline $\begin{array}{l}\text { Composite expenditures } \\
\text { a) expenses involved in maintaining durable means of production }\end{array}$ & 216,14 & 205,8 & 1,32 & 1,25 \\
\hline b) production preparation and development costs & 267,6 & 270,0 & 1,63 & 1,65 \\
\hline c) outsourced works and services & 28,5 & 25,4 & 0,17 & 0,15 \\
\hline d) indirect costs for works and services & 19,29 & 20,1 & 0,12 & 0,12 \\
\hline e) Other production costs & 588,2 & 580,2 & 3,58 & 3,54 \\
\hline $\begin{array}{l}\text { Production losses } \\
\text { a) losses due to rejects }\end{array}$ & 61,4 & 60,4 & 0,37 & 0,36 \\
\hline b) losses due to animal mortality & - & - & - & - \\
\hline c) other losses & 28,9 & - & 0,18 & - \\
\hline $\begin{array}{l}\text { 2. Constant Expenses (semi-fixed costs) } \\
\text { 2.1. General expenses of production on management }\end{array}$ & 248,6 & 250,0 & 1,52 & 1,52 \\
\hline 2.2. General economic expenses & 96,6 & 95,4 & 0,59 & 0,58 \\
\hline Total of expenses & 4530,4 & 4500,8 & 27,62 & 27,44 \\
\hline
\end{tabular}

\subsection{Cost accounting for object of costing and revenue unit of service}

\begin{tabular}{|c|l|c|}
\hline Item № & Indicators & Amount, rub. \\
\hline \multirow{2}{*}{1.} & Actual amount of expenses on horse reproductive herd housing, including: & 4530481 \\
\cline { 2 - 3 } & - side line produce costs & 291420 \\
\hline \multirow{2}{*}{2.} & Costs allocation:- share of expenses charged to mare's milk & $80 \%$ \\
\cline { 2 - 3 } & - share of expenses charged to horse foals & $20 \%$ \\
\hline 3. & Expenses involved in production by deducting side-line products & 4239061 \\
\hline 4. & Expenses involved in mare's milk & 3391248 \\
\hline 5. & Expenses involved in foal crop & 847813 \\
\hline \multirow{2}{*}{6.} & $\begin{array}{l}\text { Produced: - mare's milk, centners } \\
\text { - foal crop, heads }\end{array}$ & 1311,08 \\
\hline \multirow{2}{*}{7.} & Actual costs:- 1 centner of mare's milk & 127 \\
\cline { 2 - 3 } & -1 foal head & 2586,6 \\
\hline
\end{tabular}

\subsection{Correlation of budget cost up to the level of actual costs, rub.}

\begin{tabular}{|c|c|c|c|c|c|c|c|c|}
\hline \multirow{2}{*}{$\begin{array}{c}\text { Item } \\
\text { No }\end{array}$} & $\begin{array}{c}\text { Product } \\
\text { designation }\end{array}$ & \multicolumn{2}{|c|}{ Actual costs, rub. . } & \multicolumn{2}{c|}{$\begin{array}{c}\text { Cost in budget estimation, } \\
\text { rub. }\end{array}$} & \multicolumn{2}{|c|}{ The amount of correlation, rub. } \\
\cline { 3 - 9 } & Total & $\begin{array}{c}1 \text { revenue unit of } \\
\text { service }\end{array}$ & Total & $\begin{array}{c}1 \text { revenue unit of } \\
\text { service }\end{array}$ & $\begin{array}{c}\text { «+», } \\
\text { «-» }\end{array}$ & Total & $\begin{array}{c}1 \text { revenue unit of } \\
\text { service }\end{array}$ \\
\hline 1. & Mare's milk & 3391248 & 2586,6 & 3005528 & 2292,4 & + & 385720 & 294,2 \\
\hline 2. & Foal crop & 847813 & 6675,7 & 824228 & 6380,3 & + & 23585 & 295,4 \\
\hline
\end{tabular}




\subsection{Cost-accounting difference writing-off}

\begin{tabular}{|c|l|c|c|c|}
\hline $\begin{array}{c}\text { Item } \\
\text { № }\end{array}$ & Items of product use & Quantity & $\begin{array}{c}\text { Cost-accounting difference («+»revaluation } \\
\text { surplus; «-» reversing entry) }\end{array}$ & $\begin{array}{c}\text { Corresponding } \\
\text { account (Dt) }\end{array}$ \\
\hline 1. & Sold & $1500 \mathrm{~kg}$ & + & 90 \\
\hline 2. & Rearers (and fatteners) & $\begin{array}{c}127 \\
\text { heads }\end{array}$ & + & 11 \\
\hline 3. & $\begin{array}{l}\text { Sent to recycling in the same } \\
\text { organization }\end{array}$ & 129608 & + & 20.3 \\
\hline
\end{tabular}

\section{Conclusions}

As can be seen from the above, production cost accounting (throughput accounting) in the conventional accounting practice presents a part of the common system of book records. While doing so, the proper accounting (financial) records and production process accounting are interdetermined and interrelated since both of them have the same procedures of business transactions documentation and their valuation base. Besides, the data of the uniform accounting system can be converted either into financial or into management information system depending on the user's goals.

Moreover, the criteria of financial accounting primarily characterizing the financial status and the organization financial performance in whole can be supplemented by operational information and inner accounting reports submitted by financially accountable persons what gives the possibility to assess the efficiency of production engineering in any production area. In such a case, the accounting acquires managerial positioning since it is the accounting structure being recommended by the requirements of International Financial Reporting Standards [3].

\section{References}

Methodological recommendations on book records of production cost accounting at the agricultural enterprises (authorized by the order of the RF Ministry of Agriculture dated October, 22, 2008 № 56) // Legal Reference System «Consultant plus».

Klychova G.S. Special aspects of production costs accounting in fur farm industry / G.S. Klychova, A.R. Zakirova, A.S. Klychova // Bulletin of Kazan State Agrarian University. - 2012. - V. 25. - №3. - pp. 20-26.

Klychova G.S. Costs accounting enhancement and production costs calculation at agricultural enterprises/ G.S. Klychova, A.R. Zakirova// Economy of agricultural undertakings and processing companies. - 2003. - № 3. - pp. 30-31.

Klychova G.S The arrangement of production cost accounting in horse husbandy/ G.S. Klychova, A.R. Zakirova, M.V. Khametova//Bulletin of Kazan State Agrarian University. - 2013. - V. 28. - №2. - P. 29-25.

Klychova G.S., Iskhakov A.T. Solar batteries use in agriculture and energy accounting // Mediterranean Journal of Social Science. 2014. - № 12. - pp. 187-191.

Fakhretdinova, E.N. Accounting reporting of small and medium business as the basis of management mechanism information support/ E.N. Fakhretdinova//RISK. Resources, Information, Supply, Competition. - M.: ITKOR. - 2010. - № 4. - pp. 427-432.

Horngren Ch. T., Foster J. Book Records: management accounting aspect/ Translated from English under the editorship of Ya. V. Sokolov. - M.: Finance and Statistics, 2000. $-576 p$.

CH.T. Horngren, Foster. J., 2000. Accounting: administrative aspect: trans. from English. / Ed. Ya.V.Sokolova. Moscow: Finance and Statistics, 576 p. (in Russian)

Garifullin K.M., Klychova G.S., Zakirova A.R., 2010. The development of cost accounting in the system of internal control. Agriculture Organization, Kazan center of innovation. Technology, 307 p. (in Russian)

Shim J.K., Siegel J.G., 1998. Fundamentals of commercial budgeting. St. Petersburg.: Pergament, 496 p. (in Russian)

K.V. Shchiborshch, 2004. Budgeting activities of industrial enterprises in Russia. Moscow: Business and Service, 544 p. (in Russian). 